\title{
A Comparative Analysis: The Impact Of Non-Operating Revenues On Financial Viability Of Urban And Rural Hospitals
}

Jim Morey, SUNY Institute of Technology, USA Ken Wallis, SUNY Institute of Technology, USA Hoseoup Lee, SUNY Institute of Technology, USA Gary Scherzer, SUNY Institute of Technology, USA Robert Orilio, SUNY Institute of Technology, USA

\begin{abstract}
Fifty New York hospitals, 25 urban facilities and 25 rural facilities, were chosen at random for analysis. They were examined to determine whether non-operating revenue - contributions, gifts, grants (as defined by IRS, Form 990) - plays an important role in fiscal viability. Three years of data, 2005 - 2007, for each hospital was selected, and several financial variables were used to construct a fiscal viability index. The purpose of this study was to determine whether there is a positive difference in the fiscal health of hospitals when the hospitals can solicit more income from non-healthcare/non-operating activities in the form of outside gifts and grants. Another main purpose of this study was to determine which hospital sector, if any - urban vs. rural - is more dependent upon non-operating revenues for their fiscal viability.
\end{abstract}

\section{INTRODUCTION}

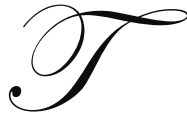

he purpose of this study was to: (1) analyze the impact of non-operating revenues on the fiscal viability of $50 \mathrm{New}$ York hospitals; and (2) examine the effect of non-operating revenue on fiscal viabilities between 25 urban facilities and 25 rural facilities. Three years of data $-2005-2007-$ was utilized in examining these issues. Non-operating revenues are defined as contributions, gifts, and grants (as defined by IRS, Form 990)

The following are the 4 hypotheses for the study:

1. Non-operating revenues such as contributions, gifts, and grants as a percentage of total revenue play an important role in the overall financial health of hospitals (Model 1).

2. Non-operating revenues have a more significant affect on the overall financial health of urban hospitals than rural ones (Model 2).

3. After controlling for the effect of hospital size, non-operating revenues affect the overall financial health of hospitals (Model 3).

4. After controlling for the effect of hospital size, urban hospitals financial health depends more on nonoperating revenues than rural ones (Model 4).

\section{METHODOLOGY}

The methodology used fiscal ratios to create a fiscal viability indexwhich in turn would be used for analysis. The various fiscal ratios employed in the index, as outlined by Cleverly (Cleverly, 1997), are presented on Table 1. 
Table 1. Variables and ratios that determine fiscal viability

\begin{tabular}{|l|l|l|}
\hline \multicolumn{1}{|c|}{ Variables } & \multicolumn{1}{|c|}{ Ratio } & \multicolumn{1}{c|}{ Formula } \\
\hline Fiscal viability from & (1) Income margin & Net income $\div$ total operating revenue \\
\cline { 2 - 3 } profitability & (2) Return on equity & Net income $\div$ unrestricted net asset \\
\hline $\begin{array}{l}\text { Fiscal viability from capital } \\
\text { structure }\end{array}$ & (3) Equity financing & Unrestricted net asset $\div$ total asset \\
\cline { 2 - 3 } & (4) Cash flow to debt & (Net income + depreciation) $\div$ total liabilities \\
\hline
\end{tabular}

Source: Cleverly, W.O. 1997. Essentials of Health Care Finance, Fourth Edition. Aspen Publication.

The financial ratios were "combined" into a fiscal viability index utilizing the calculated ratios of the sample hospitals. Specifically, the index was constructed using the following:

- $\quad$ Fiscal viability from Profitability: for each positive ratio, a score of .5 was assigned; and

- $\quad$ Fiscal viability from Capital Structure: for each positive ratio, a score of 1.0 was assigned.

Thus, an overall fiscal viability rating for each hospital ranged from 0 (low) to 3 (high). A three year average 2005 - 2007 - was utilized in developing the fiscal viability index.

\section{FINDINGS \& ANALYSIS}

\section{Descriptive Analysis of Hospital Sample}

Table 2 provides descriptive statistics of variables used in this study including the fiscal viability index and its components, non-operating revenue (\$), and total revenue (\$) in two types of hospitals (25 urban and 25 rural hospitals over three-year period). Total revenue is a combination of operating and non-operating revenue. Four variables constituting the fiscal viability index are quite volatile, especially for the return on assets and equity financing percent, justifying the conversion process used in this study.

Table 2. Descriptive Statistics of Hospital Sample by Venue ( 25 urban and 25 rural hospitals over three-year period)

\begin{tabular}{|l|c|c|c|c|c|c|c|c|}
\hline \multirow{2}{*}{ Variable } & \multicolumn{9}{|c|}{ Hospitals } & \multicolumn{3}{c|}{ Rural } \\
\cline { 2 - 9 } & $\mathbf{N}$ & Mean & $\begin{array}{c}\text { Standard } \\
\text { deviation }\end{array}$ & Median & N & Mean & $\begin{array}{c}\text { Standard } \\
\text { deviation }\end{array}$ & Median \\
\cline { 2 - 9 } $\begin{array}{l}\text { Fiscal Viability } \\
\text { (FV) }\end{array}$ & 75 & 2.58 & 0.73 & 3 & 75 & 2.27 & 0.92 & 3 \\
\hline $\begin{array}{l}\text { FV } \\
\text { (Net income } \\
\text { margin) }\end{array}$ & 75 & 0.42 & 0.18 & 0.5 & 75 & 0.33 & 0.24 & 0.5 \\
\hline $\begin{array}{l}\text { FV (Return on } \\
\text { equity) }\end{array}$ & 75 & 0.37 & 0.22 & 0.5 & 75 & 0.27 & 0.25 & 0.5 \\
\hline $\begin{array}{l}\text { FV (Capital } \\
\text { structure) }\end{array}$ & 75 & 0.85 & 0.36 & 1 & 75 & 0.8 & 0.4 & 1 \\
\hline $\begin{array}{l}\text { FV (CF over } \\
\text { debt) }\end{array}$ & 75 & 0.93 & 0.12 & 1 & 75 & 0.87 & 0.34 & 1 \\
\hline $\begin{array}{l}\text { Non-operating } \\
\text { revenue* }\end{array}$ & 75 & $\$ 18,571$ & $\$ 29,710$ & $\$ 3,387$ & 75 & $\$ 684$ & $\$ 848$ & $\$ 517$ \\
\hline $\begin{array}{l}\text { Total } \\
\text { revenue* }\end{array}$ & 75 & $\$ 656,489$ & $\$ 642,286$ & $\$ 386,512$ & 75 & $\$ 66,640$ & $\$ 130,578$ & $\$ 53,738$ \\
\hline
\end{tabular}

$*$ in thousands

As indicated in Table 2, and as we expected, urban hospitals in the sample are much larger than rural hospitals with total revenue of more than $\$ 656$ million, compared just over $\$ 66$ million of revenue in rural hospitals. The amount of non-operating revenue in both samples show similar pattern; much bigger dollar amounts from 
contributions, gifts, and grants (more than $\$ 18$ million) for urban hospitals, compared to less than $\$ 700,000$ for rural hospitals.

For the fiscal viability index, there are no meaningful differences between urban and rural hospitals. In general, urban hospitals in the sample show higher profitability, higher return on equity, bigger unrestricted net assets as a percentage of total assets, and higher cash flows over debt, compared to rural hospitals.

\section{Analysis of Model 1 - Impact of non-operating revenues on fiscal viability}

This model examines the overall effect of non-operating revenue (as a percentage of total revenue) on the fiscal viability of hospitals. As presented in Table 3, no significant positive effect of non-operating revenue was found. Instead, the result shows a negative impact of non-operating revenue on fiscal viability, which indicates that when hospitals generate more income from contributions, gifts, and grants, their overall financial conditions either tend to deteriorate or they already had begun to deteriorate and they sought more non-operating revenue.

Table 3. Effect of Non-operating Revenue as Percentage of Total Revenue on Fiscal Viability $(\mathbf{N}=150)$

\begin{tabular}{|l|c|c|}
\hline \multicolumn{1}{|c|}{ Variable } & Coefficient & t-value \\
\hline Intercept & 2.48 & $24.2 * * *$ \\
\hline Non-operating \% & -3.21 & -0.73 \\
\hline R-square & \multicolumn{2}{|c|}{$0.36 \%$} \\
\hline F-value & \multicolumn{2}{|c|}{0.53} \\
\hline
\end{tabular}

Significance level: $* * *(1 \%)$ 3. Analysis of Model 2 - Impact of non-operating revenues on fiscal viability of urban vs. rural
hospitals

The overall insignificant effect of non-operating revenue in Model 1 may be due to the differing funding needs between urban and rural hospitals. With a greater research/teaching capability, large urban hospitals may depend much more on external funding such as contributions, gifts, and grants for financial survival than small rural hospitals, which focus primarily on revenues generated from providing healthcare services to their patients.

To examine the differing effect, separate analyses were performed on each type of hospital - one for urban hospitals and the other for rural hospitals. Table 4 examines the differing effect on non-operating revenues between urban and rural hospitals. For both urban and rural hospitals (Model 1), the impact of non-operating revenue on fiscal viability was negative and insignificant. But, the relative negative impact is much smaller for urban hospitals $(-2.38)$ than for rural ones (-6.57). In other words, urban hospitals tend to have better financial outcomes than rural hospitals do when urban hospitals can generate more income from external contributions, gifts, and grants.

Table 4. Effect of Non-operating Revenue as Percentage of Total Revenue on Fiscal Viability for Urban and Rural Hospital Samples

\begin{tabular}{|l|c|c|c|c|}
\hline \multicolumn{1}{|c|}{ Variable } & \multicolumn{2}{c|}{ Urban Hospitals (N=75) } & \multicolumn{2}{c|}{ Rural Hospitals (N=75) } \\
\hline & Coefficient & t-value & Coefficient & t-value \\
\hline Intercept & 2.62 & $19.61 * * *$ & 2.37 & $15.8 * * *$ \\
\hline Non-operating \% & -2.38 & -0.44 & -6.57 & $-6.86^{* * *}$ \\
\hline R-square & \multicolumn{2}{|c|}{$0.26 \%$} & \multicolumn{2}{c|}{$1.24 \%$} \\
\hline F-value & \multicolumn{2}{|c|}{0.19} & \multicolumn{2}{c|}{0.92} \\
\hline
\end{tabular}

Significance level: *** (1\%)

To examine the significance of the differing impact of non-operating revenue on financial viability between urban and rural hospitals, we introduced a dummy variable of non-operating revenue (\%) for urban hospitals into Model 1. This dummy variable is to capture the additional effect of non-operating revenue on the fiscal viability of urban hospitals. 
As presented in Table 5, the impact of non-operating revenue on the fiscal viability of urban hospitals (dummy variable) is much greater and statistically significant. The impact of non-operating revenue on fiscal viability for overall hospitals is very negative (-10.29; statistically significant at $10 \%$ level), but the impact for urban hospitals is significantly positive (12.38; significant at $5 \%$ level). This result indicates that urban hospitals can improve their financial health by generating more income from external sources such as contributions, gifts, and grants. In other words, urban hospitals' financial health depends more on funding from external sources; in other words, they may be less reliant on traditional income from providing healthcare services to their patients.

Table 5. Differing Effect of Non-operating Revenue as Percentage of Total Revenue on Fiscal Viability between Urban and Rural Hospitals ( $N=150)$

\begin{tabular}{|l|c|c|}
\hline \multicolumn{1}{|c|}{ Variable } & Coefficient & t-value \\
\hline Intercept & 2.48 & $24.51 * *$ \\
\hline Non-operating \% & -10.29 & $-1.87 *$ \\
\hline Urban Hospital \% (dummy variable) & 12.38 & $5.88 * *$ \\
\hline R-square & \multicolumn{2}{|c|}{$3.27 \%$} \\
\hline F-value & \multicolumn{2}{|c|}{$2.49 *$} \\
\hline
\end{tabular}

Significance level: $* * *(1 \%) ; * *(5 \%) ; *(10 \%)$

\section{Analysis of Model 3 - Impact of non-operating revenues and hospital size on fiscal viability}

An additional factor we examined in this study was the potential impact of hospital size on fiscal viability, coupled with non-operating revenue. The main reason for adding size into the model is to control the potential interference of hospital size with the impact of non-operating revenue on fiscal viability. We used the amount of total revenue (combination of operating and non-operating revenue) as a proxy for the hospital size.

As indicated in Table 6, hospital size plays an important role in explaining fiscal viability. The result shows that bigger hospitals tend to have better financial viability, and the positive effect is statistically significant (0.038; significant at $1 \%$ level). The impact of non-operating revenue is still negative and significant at $10 \%$ level.

Table 6. Effect of Non-operating Revenue as Percentage of Total Revenue on Fiscal Viability after Controlling Size of Hospitals ( $N=150)$

\begin{tabular}{|l|c|c|}
\hline \multicolumn{1}{|c|}{ Variable } & Coefficient & t-value \\
\hline Intercept & 2.43 & $23.96 * * *$ \\
\hline Non-operating \% & -8.45 & $-1.8^{*}$ \\
\hline Size - Total Revenue (\$) & 0.038 & $2.81^{* * *}$ \\
\hline R-square & \multicolumn{2}{|c|}{$5.42 \%$} \\
\hline F-value & \multicolumn{2}{|c|}{$4.22^{* *}$} \\
\hline
\end{tabular}

Significance level: $* * *(1 \%) ; * *(5 \%) ; *(10 \%)$

\section{Analysis of Model 4 - Impact of non-operating revenues and hospital size on fiscal viability of urban vs. rural hospitals}

We also applied the hospital size into its differing effect on fiscal viability between urban and rural hospital. Compared to Table 5, Table 7 shows a less positive effect of urban hospitals (12.38 to 2.43) which is not statistically significant. The impact of hospital size on fiscal viability is positive (0.034) and significant at $10 \%$ level. The less significant effects of both urban hospital and hospital size on fiscal viability may be due to collinearity between two variables. The correlation factor between two variables is more than 75 percent, and their effect on fiscal viability is similar in their behavior. 
Table 7. Differing Effect of Non-operating Revenue as Percentage of Total Revenue on Fiscal Viability between Urban and Rural Hospitals after Controlling Size ( $\mathbf{N}=150)$

\begin{tabular}{|l|c|c|}
\hline \multicolumn{1}{|c|}{ and Rural Hospitals after Controlling Size (N =150) } \\
\hline Intercept & Coefficient & t-value \\
\hline Non-operating \% & 2.44 & -1.7 \\
\hline Urban Hospital \% (dummy variable) & -9.32 & 0.31 \\
\hline Total Revenue (\$) & 2.43 & $1.85 *$ \\
\hline R-square & 0.034 & \\
\hline F-value & \multicolumn{2}{c|}{$5.49 \%$} \\
\hline
\end{tabular}

Significance level: $* * *(1 \%) ; * *(5 \%) ; *(10 \%)$

\section{ANALYSIS OF FINDINGS}

Among four models tested in this study, the results of Models 2, 3 (partial), and 4 (partial) show the outcomes as expected in the corresponding hypotheses.

With Model 2, the result indicates that urban hospitals show more dependence on non-operating revenue for their financial viability, than rural hospitals do. In other words, urban hospital may experience greater financial difficulty without external contributions, gifts, and grants.

With Model 3, hospital size plays an important positive role in the financial health of hospitals. The greater the revenue (operating and non-operating) hospitals generate, the less likelihood of financial difficulty. The effect of non-operating revenue on the financial health of hospitals is still negative with this model.

With Model 4, both hospital size and being urban have a positive effect on the financial health of hospitals.

\section{CONCLUSION}

1. Non-operating revenues like contributions, gifts, and grants as a percentage of total revenue play an important role in the overall financial health of hospitals (Model 1)

Conclusion: The data did not support this assumption.

2. Non-operating revenues play a differing role in the overall financial health more for urban hospitals than rural ones (Model 2).

Conclusion: The data supported this result with a positive impact on urban hospitals, and negative impact on rural hospitals.

3. After controlling for the effect of hospital size, non-operating revenues affect the overall financial health of hospitals (Model 3).

Conclusion: The data was inconclusive in terms of overall financial health impact, but the larger the size (revenue) of the hospital, the more significant impact of non-operating revenues on fiscal viability.

4. After controlling for the effect of hospital size, the financial health of urban hospitals depends more on non-operating revenues than that of rural ones.

Conclusion: The larger the size of the hospital, the greater the significance of non-operating revenues on fiscal viability. When the dummy variable is used, the results are inconclusive.

\section{REFERENCES}

1. Cleverly, W.O. 1997. Essentials of Health Care Finance, Fourth Edition. Aspen Publication.

2. "IRS Form 990” for years 2005 - 2007; www.Guidestar.org 


\section{NOTES}

